\title{
RESULTS OF BLADDER TRAINING 1966-1974
}

\author{
By Ragnar N. Gjone, M.D. and Egil Ween, M.D. \\ Sunnaas Hospital, Norway
}

Key words: Bladder training; Intermittent catheterisation; Residual urine; Autonomous and reflex bladders.

SunnaAs SykeHus, the Sunnaas Hospital, is a municipal institution for Medical Rehabilitation for Oslo, Norway, with 247 beds.

The Hospital has a special 25-bed Spinal Cord Unit. Approximately 40 new cases from all over the country have been admitted each year for the last few years, and in addition some 25 patients return for regular check-up. Our figures indicate about 60 new spinal cord injuries per year in Norway, or I 5 new cases per million inhabitants per year. This corresponds with findings elsewhere. Precise statistics will be published later.

In Scandinavia spinal cord injuries are primarily treated in surgical and neurosurgical institutions. It may take days or even weeks, in our case an average of 8 weeks, before the patient is referred to the Rehabilitation Clinic.

On admission to the Sunnaas Hospital the patient will start bladder training, emptying the bladder at set hours during the day, five times in 24 hours, the first four times subsequent to intake of a determined amount of fluid. The patient will be intermittently catheterised and will be trained to control bladder emptying by expression or suprapubic tapping. Residual urine up to $200-300 \mathrm{ml}$ is considered acceptable during the first weeks. If this regime, which includes the use of various types of pharmaca, does not meet with success the patient will be referred to the Municipal Urological Department for evaluation.

The object of this follow-up study has been to assess both the results of our primary bladder training and the urological status and bladder emptying habits at the follow-up.

\section{Materials and Methods}

The material originally consisted of I 52 patients admitted to the Hospital during the 9-year period I966-I974. All patients were traumatic spinal cord injuries, about 40 per cent incomplete lesions, 85 per cent males. The mean age

TABLE I

Traumatic spinal cord injuries I966-74

\begin{tabular}{lrlr}
\hline \multicolumn{1}{c}{ Level } & \multicolumn{2}{l}{ Cases } & \\
\cline { 2 - 3 } Cervical & 76 & Male & 127 \\
Thoraco/lumbo/sacral & 64 & Female & 25 \\
Cauda equina & I2 & Mean age & 30 \\
Total & I52 & & \\
\hline
\end{tabular}


was 30 years (Table I). These patients had all initially been treated with permanent catheters. Case histories gave adequate data on the primary handling of bladder problems in I 6 of these patients. In some cases the catheter was removed on admission without, however, a subsequent bladder regime.

During September I975 questionnaires were sent to all I 52 patients. We received answers to II 2 of these. In the course of April-June 1976 we performed urological check-ups on $7 \mathrm{I}$ of these patients, with urine analysis, residual urine and IVP. Where pathological conditions were found kidney function was examined.

\section{Results}

On discharge, 23 of the II 6 patients had regained complete control with spontaneous voiding (Table II). These were all cases of incomplete spinal lesions. Twenty-two patients developed autonomous bladders and effected voiding by abdominal pressure or manual expression. There were 68 cases of reflex bladder. Only three patients were discharged with indwelling catheters, successful emptying having proved impossible mainly because of the ages of these patients.

An average of 8 weeks was needed to gain control in cases of reflex bladders

TABLE II

Bladder-emptying pattern in I 6 patients on discharge

\begin{tabular}{lccccc}
\hline \multicolumn{1}{c}{ Type of bladder } & \multicolumn{5}{c}{ Level of spinal injury } \\
& Cervical & Dorsal & Lumbar & $\begin{array}{c}\text { Conus } \\
\text { Cauda }\end{array}$ & Total \\
\hline Upper motor neurone & 45 & 2I & 2 & - & 68 \\
Lower motor neurone & - & 6 & II & 5 & 22 \\
Indwelling catheter & I & I & I & -4 & 3 \\
Normal voiding & I3 & 3 & 3 & 4 & 23 \\
Total & 59 & 3I & I7 & 9 & II6 \\
\hline
\end{tabular}

TABLE III

Time required to establish balanced bladder function related to bladder type and level of spinal cord injury (in weeks)

\begin{tabular}{|c|c|c|c|c|c|}
\hline \multirow[t]{2}{*}{ Type of bladder } & \multicolumn{5}{|c|}{ Level of spinal injury } \\
\hline & Cervical & Dorsal & Lumbar & $\begin{array}{l}\text { Conus } \\
\text { Cauda } \\
\text { eq. }\end{array}$ & Mean \\
\hline $\begin{array}{l}\text { Upper motor neurone } \\
\text { Lower motor neurone }\end{array}$ & $\mathrm{N} \stackrel{7 \frac{1}{2}}{=} 45$ & $\begin{array}{c}\mathrm{9} \\
\mathrm{N}=2 \mathrm{I} \\
\mathrm{I} 4 \\
\mathrm{~N}=6\end{array}$ & $\begin{array}{l}\mathrm{N}=2 \\
\mathrm{~N} \\
\mathrm{~N}=\mathrm{II}\end{array}$ & $\begin{array}{c}- \\
\mathrm{N} \\
=5\end{array}$ & $\begin{array}{c}8 \\
\mathrm{~N}=68 \\
9 \frac{1}{2} \\
\mathrm{~N}=22\end{array}$ \\
\hline
\end{tabular}


and $9 \frac{1}{2}$ weeks in autonomous bladders (Table III). The younger the patient, the quicker this control was achieved (Table IV). Of the patients with non-spontaneous emptying, 55 had undergone urological control the last week before discharge. Our findings were as follows (Table V): 80 per cent had physiological urine according to routine examinations and urine micro; 65 per cent had sterile urine (less than $\mathrm{IO}^{-5}$ bacteria per $\mathrm{ml}$ ). IVP indicated a slight degree of hydronephrosis or hydroureter in I I per cent of the cases. Io per cent had bladder diverticuli. We found bladder stones in 23 per cent of the cases; all of these had suffered repeated infections. There was normal kidney function in all cases, with physiological urine and normal values for urea and creatinine in serum. Residual urine immediately prior to discharge showed values ranging from 0 to $220 \mathrm{ml}$; in 80 per cent of the patients less than i $50 \mathrm{ml}$, mean value $75 \mathrm{ml}$ (Table VI).

\section{TABLE IV}

Average time of catheterisation before established balanced bladder function related to age $(\mathrm{N}=90)$ (in weeks)

\begin{tabular}{rrc}
\hline \multicolumn{1}{c}{ Age } & Cases & Time \\
\hline 20 & 28 & 6 \\
$2 \mathrm{I}-40$ & 30 & $7 \frac{1}{2}$ \\
$4 \mathrm{I}-60$ & 23 & 9 \\
$6 \mathrm{I}-$ & 9 & $\mathrm{I} 3 \frac{1}{2}$ \\
Total & 90 & \\
\hline
\end{tabular}

\section{TABle V}

Urological status of 55 patients on discharge

\begin{tabular}{lrc}
\hline & Cases & $\%$ \\
\hline Urine: micro neg. & 44 & 80 \\
$\quad$ bact. neg. & 20 & 65 \\
Diverticuli of bladder & 5 & IO \\
Hydronephrosis (slight) & 6 & I I \\
Bladder stones & I3 & 23 \\
\hline
\end{tabular}

\section{TABLE VI}

Residual urine on discharge $(\mathrm{N}=55)$

\begin{tabular}{lcc}
\hline & Cases & $\%$ \\
\hline Low (less than I50 ml) & 45 & 80 \\
High (more than I50 ml) & I0 & 20 \\
Total & 55 & I00 \\
\hline
\end{tabular}

Mean: $75 \mathrm{ml}$. 
Our follow-up study showed that bladder-emptying patterns had undergone no major changes (Table VII). For various reasons indwelling catheters were in use in the case of five patients who on discharge had reflex bladders. A further analysis indicates that patients tend to establish an emptying pattern in the course of the first two to three years following discharge-a pattern less strictly timed both as to intake and emptying (Table VIII). Approximately half the patients prefer urinals or pads.

Repeated urinary infections had occurred in 35 per cent of the cases of reflex bladder and in 55 per cent of those with autonomous bladders (Table IX). Acceptable quantities of residual urine (Table X) were found in 65 per cent of the cases (less than $150 \mathrm{ml}$ ), 4 per cent, had indwelling catheters. In one case of incontinence the patient was discharged with an ileum bladder. In this case bladder training had proved impracticable, due to a reactive psychosis.

\section{IVP Results}

IVP examinations gave the following results: I4 per cent had pathological IVP findings, as compared to I I per cent on discharge.

TABLE VII

Bladder-emptying pattern in I22 patients. Follow-up study I 975

\begin{tabular}{lcc}
\hline \multicolumn{1}{c}{ Type of bladder } & \multicolumn{2}{c}{ No. of patients } \\
\cline { 2 - 3 } & $\begin{array}{cc}\text { Initial } \\
\text { discharge }\end{array}$ & 1975 \\
\hline Upper motor neurone & 65 & 60 \\
Lower motor neurone & 18 & I8 \\
Indwelling catheter & 3 & 8 \\
Normal voiding & 36 & 36 \\
\hline
\end{tabular}

TABLE VIII

Bladder-emptying habits related to years since discharge. Follow-up study 1975 $(\mathrm{N}=$ 103)

\begin{tabular}{|c|c|c|c|c|c|}
\hline \multicolumn{2}{|c|}{ Number of } & \multicolumn{2}{|c|}{ Set hours for } & \multirow[t]{2}{*}{ Medication } & \multirow[t]{2}{*}{ Continent } \\
\hline Years & Cases & Drinking & Emptying & & \\
\hline I & 0 & - & - & - & - \\
\hline 2 & I5 & IO & I2 & IO & 5 \\
\hline 3 & I 4 & 5 & 6 & 9 & 7 \\
\hline 4 & I7 & 6 & 7 & 6 & 7 \\
\hline 5 & I5 & 5 & 4 & 6 & 6 \\
\hline 6 & I5 & 4 & 7 & 8 & 7 \\
\hline 7 & 6 & 6 & 2 & 3 & 3 \\
\hline 8 & 9 & 4 & 5 & 5 & 4 \\
\hline 9 & 5 & I & 2 & 2 & 2 \\
\hline I0 & 7 & 2 & I & 4 & 5 \\
\hline
\end{tabular}


TABLE IX

Repeated infections after discharge. Follow-up study 1975-76

\begin{tabular}{rcc}
\hline Type of bladder & Cases & $\%$ \\
\hline $\begin{array}{l}\text { Upper motor neurone } \\
(\mathbf{N}=60)\end{array}$ & $2 \mathrm{I}$ & 35 \\
$\begin{array}{l}\text { Lower motor neurone } \\
(\mathrm{N}=\mathrm{I} 8)\end{array}$ & I0 & 55 \\
\hline
\end{tabular}

TABLE X

Residual urine at follow-up study $(\mathrm{N}=7 \mathrm{I})$

\begin{tabular}{lrr}
\hline & Cases & $\%$ \\
\cline { 2 - 3 } & & \multicolumn{1}{c}{ \%ow (less than I50 ml) } \\
High (more than I50 ml) & 45 & 65 \\
Permanent catheter & 3 & 30 \\
Ileum bladder & I & I \\
\hline
\end{tabular}

\section{Data on Admission}

\section{Comments}

Our follow-up study shows that bladder training with intermittent catheterisation can lead to a balanced bladder function in a reasonably short time (8-Io weeks), even if there is a considerable lapse of time between injury and an established bladder routine. Studies by Vivian and Bors (1972) support these findings.

Our young patients reached a balanced bladder control quicker than the older ones. Vivian and Bors (1972) have shown that patients under 50 more easily gain control than those over 50 . Within a certain age limit, the younger the patient the easier it seems to gain control.

Residual urine was reduced to acceptable quantities in good time before discharge. If necessary this was done with the help of surgery, as in the case of five of our patients (three TUR, one prostatectomy, one extern sphincter resection). 20 per cent of our patients still did not meet our standards as to residual urine immediately prior to discharge, but in no case did the quantities exceed $220 \mathrm{ml}$. We find this result acceptable, as does Gibbon (1974). As a result of this liberal attitude towards residual urine requirements, the number of patients discharged without catheter has been as high as 96 per cent as compared to 26-95 per cent noted by other authors (Bors \& Camarr, I97I).

A total of 23 per cent was treated for bladder stones during hospitalisation. In most cases stones had formed before admission. This rather high percentage can only be ascribed to the fact that the patients had been treated with indwelling catheters prior to admission, had non-sterile urine and had been immobilised, thus being susceptible to stone formation (Guttmann, 1973). We do not consider bladder stones as representing a serious threat to normal kidney function and in this we have the support among others of Price et al. (1972). However, stones do tend to impede a balanced bladder function. 
As to the incidence of pathological changes as disclosed by IVP tests we have found hydronephrosis in I I per cent of our patients. Other authors have noted approximately 20 per cent (Scher, 1975; Ascoli, 1970). As a single phenomenon hydronephrosis probably does not represent a danger of kidney damage but it does signal the necessity of being aware of possible urinary complications.

All the patients studied had pyuria on admission. On discharge 60 per cent had sterile urine. These values may be somewhat misleading since some of the patients were receiving urinary antiseptic medication at the time of the test, but our results are in accordance with similar tests, as shown by Vivian and Bors (1972).

\section{Data at Check-up}

Check-up indicated that drinking and emptying habits had changed since discharge. Only half the patients had kept to a regular schedule and many patients had adapted this to their own individual routine. In quite a few cases emptying was effected on signals from accompanying autonomous phenomena, such as headaches or sweating. Half the patients used urinals or pads. These were preferred for socio-psychological reasons even if not imposed by necessity.

There was a tendency to increased residual urine after discharge from hospital. In fact, 35 per cent of our patients had more than $150 \mathrm{ml}$ as opposed to 20 per cent on discharge. Despite the fact that none had more than $350 \mathrm{ml}$, these findings do emphasise the need for regular control of residual urine also after discharge.

Registered as flare-ups and pyuria at check-up the rate of urinary infection was 40 per cent of all patients. However, patients with autonomous bladders seemed more susceptible to infection than patients with reflex bladders. These findings are supported by other studies (Sher, 1975), showing a higher frequency of X-ray revealed pyelonephritic changes in paraplegics than in tetraplegics.

Our IVP results after the follow-up showed very few pathological changes of the upper urinary tract. The frequency of hydronephrosis and hydroureter seems unchanged, while we found a small increase in the number of pyelonephritic changes. Even so, our figures (three of $7 \mathrm{I}$ patients, or 4 per cent) are low compared to Sher's findings (I975), but then our period of observation may be too short for conclusions.

Our patients had suffered few other complications after discharge. Of the I52 patients, two had been treated surgically for kidney stones, one had been operated on for a ureter stone and one had been treated for prostate adenoma. Two patients had shown signs of kidney failure. Only three of the six deaths which occurred after discharge can be ascribed to the initial spinal injury (two cases of pyelonephritis and one of subarachnoidal haemorrhage subsequent to an autonomous crisis).

\section{TABLE XI}

Follow-up study 1975-76. Mean time of observation $4 \frac{1}{2}$ years

$$
\text { (I-IO years) }(\mathrm{N}=7 \mathrm{I})
$$

\begin{tabular}{|c|c|c|}
\hline IVP findings & Cases & $\%$ \\
\hline Negative IVP & 62 & 86 \\
\hline Hydronephrosis & 6 & 9 \\
\hline Chronic pyelonephritis & 3 & 4 \\
\hline Nephrolithiasis & I & I \\
\hline
\end{tabular}




\section{Conclusions}

I52 patients with spinal injury have been treated at the Sunnaas Hospital during the period I966-I974. Registration of urological data was done in 55 of these cases prior to discharge and 7I cases were included in a follow-up study. A study was made of the bladder-emptying habits of II 2 patients with a mean observation period of $4 \frac{1}{2}$ years.

The study indicates that most patients will gain balanced function through bladder training and intermittent catheterisation. In spite of a liberal attitude in the question of residual urine and for medical therapy in preference to surgical intervention whenever possible, we have seen few pathological changes of the upper urinary tracts. The use of indwelling catheter in the acute stage of the injury contributes to infections and stone formation but does not seem to represent a serious impediment to a balanced bladder function. A bladder-emptying regime must be planned in good time before discharge and must take into consideration the patient's individual daily routine. The regime must include regular check-ups, with urine tests, residual urine checks, and IVP, complemented by special examinations of possible pathological changes of the upper urinary tract.

\section{RÉSUMÉ}

Durant les années de 1966 à 1974 on a traité un total de 152 lésions médullaires au Centre de Médecine Physique et de Réhabilitation, Sunnaas sykehus Oslo. On était en possession d'un bilan urologique pour 55 patients, renseignements enregistrés immédiatement avant la sortie de l'hôpital. 7I lésions médullaires sont inclus dans une nouvelle étude de contrôle. On a fait l'étude des habitudes de vidage de la vessie de I I 2 patients avec une durée moyenne d'observation $4 \frac{1}{2}$ années.

Les résultats de cette étude nous montrent que la plupart des patients atteint une fonction vesiculaire balancée, en adoptant un régime d'entrainement et de catheterisation intermittante.

Malgré la politique libérale adoptée à l'égard des quantités admissibles d'urine résiduelle et malgré le choix d'une thérapie médicale en préférence à l'intervention chirurgique, nous n'avons registré que de modestes modifications pathologiques des voies urinaires supérieures.

L'usage de chathètre pérmanent durant la phase aigue de la lésion dispose à l'infection et à la formation de calculs vesiculaires, mais ne parait pas représenter d'obstacle à l'établissement d'une fonction balancée de la vessie.

On doit s'èfforcer à établir un programme de vidage de la vessie bien à l'avance de la sortie de l'hôpital et s'appliquer à incorporer ce régime à la routine individuelle du malade. Il doit inclure des contrôles réguliers, avec des examens d'urine, contrôles d'urine résiduelle et des tests IVP, ainsi que des examens complémentaires pour la détection de modifications pathologiques des voies urinaires supérieures.

\section{ZUSAMMENFASSUNG}

I52 Patienten mit Querschnittlähmungen wurden im Sunnaas Hospital von I9661974 behandelt. Urologische Befunde wurden in 55 Fällen bevor der Entlassung erhoben

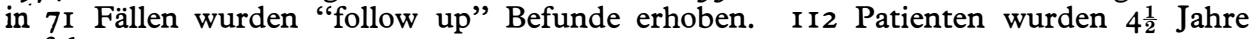
verfolgt.

Die Studie ergab eine balancierte Funktion der Blase in den meisten Fällen durch intermittierende Katheteriserung und Blasentraining. Geringe pathologische Veränderungen im obern Harntrakt als Folge von Residualharn wurden beobachtet trotz bevorzugter konservativer Behandlung.

Dauer Katheter im akuten Stadium der Lähmung verursacht Infektion und Steinformation, bildet aber keine schwere Behinderung für die Entwicklung einer balancierten Blasenfunktion. 


\section{REFERENCES}

AsColi, R. \& Franch (1970). Paraplegia, 8, 196.

Bors, E. \& Comarr, A. (I97I). Neurological Urology. Gibbon, N. O. K. (1974). Paraplegia, 12, 87.

GuttmanN, L. (1973). Spinal Cord Injuries. Comprehensive Management and Research. Blackwell Scientific Publications.

Price, M., KotTKe, F. J. \& Olson, M. E. (1972). The eighth year of a ten-year follow-up of renal function in patients with spinal cord injury. $6^{0}$ Congreso International de Medicina Fisica. Barcelona.

SCHER, A. T. (1975). Paraplegia, 13, I57.

Vivian, M. \& BORS, E. (1972). Paraplegia, 12, I58-166.

\section{General Discussion}

Dr A. Key (S.A.). I'd just like to ask Dr Ween, in connection with the residual urine estimates that he has there, $150 \mathrm{ml}$, does this take into consideration the capacity of the bladder?

DR WeEN. I did not understand the last part of the question. Will you please repeat it?

DR KEY. The figure that you give of $\mathrm{I} 50 \mathrm{ml}$ for a residual urine, does this take into account the capacity of the bladder?

DR PERKASH (Chairman). What was the total volume of the bladder when you talk of $\mathrm{I} 50 \mathrm{cc}$ residue. Am I right that this is what you want to know Dr Key?

DR KEY. Yes I want to know if this figure takes into account-perhaps the patient has a capacity of 200 , is $150 \mathrm{ml}$ residual then satisfactory?

DR PERKASH. You have any rough idea?

DR WEEN. No. I haven't.

Dr Perkash. Well, this is an important aspect that a patient may have $200 \mathrm{cc}$ and he may have I $50 \mathrm{cc}$ residue meaning you have to have a dynamic residue while spontaneous and reflex voiding. Any other questions? Thank you, Dr Ween, it is a good paper. I think we have some language barrier probably but I'm sure you have some tremendous material and those of us who have something to ask may talk to you later on. 